\title{
IMPLEMENTASI SOCIETY 5.0 DALAM KEBIJAKAN DAN STRATEGI PENDIDIKAN PADA PANDEMI COVID-19
}

\section{ADITYA ZULMI RAHMAWAN ${ }^{1)}$, ZAENURIYAH EFFENDI ${ }^{2)}$}

1) Manajemen Bencana Sekolah Pascasarjana Universitas Airlangga

2) SMA Muhammadiyah 1 Taman

e-mail: zulmi.mail@gmail.com

\begin{abstract}
ABSTRAK
Pandemi covid-19 memberikan permasalahan di berbagai sektor. Sektor yang paling rentan dalam situasi ini adalah sektor sosial terutama pada pendidikan. Permasalahan seperti proses pembelajaran membuat keberlangsungan pendidikan menuai kekhawatiran. Hal ini menjadi sebuah tantangan bagi masyarakat di era society 5.0 dengan harapan dapat mengatasi permasalahan yang timbul akibat pandemi Covid-19. Pemanfaatan big data, artificial intelligent, dan internet of things menjadi upaya alternatif dalam membantu menangani dampak pandemi yang sesuai dengan keadaan di era disruptif ini. Penelitian ini bertujuan untuk mengetahui kebijakan dan strategi society 5.0 dalam proses pembelajaran sebagai upaya penanganan dampak pandemi. Penelitian ini menggunakan metode penelitian tinjauan sistematis terhadap literatur yang diterbitkan oleh jurnal ilmiah pada periode Januari tahun 2010 hingga Desember 2021. Sumber yang digunakan berasal dari jurnal-jurnal yang sudah dipublikasikan terkait dengan topik yang dikaji dan dari berbagai media elektronik. Hasil penelitian dapat mengetahui strategi dalam proses pembelajaran dalam implementasi society 5.0 pada kebijakan di bidang pendidikan sebagai upaya menghadapi dampak pandemi covid19.
\end{abstract}

Kata Kunci: society 5.0, pandemi, covid-19

\begin{abstract}
The COVID-19 pandemic poses problems in various sectors. The most vulnerable sector in this situation is the social sector, especially education. Problems such as the learning process make the continuity of education a concern. This is a challenge for the community in the era of society 5.0 in the hope of overcoming the problems that arise due to the Covid-19 pandemic. The use of big data, artificial intelligence, and the internet of things is an alternative effort to help deal with the impact of the pandemic in accordance with the conditions in this disruptive era. This study aims to determine the policies and strategies of society 5.0 in the learning process as an effort to handle the impact of the pandemic. This study uses a systematic review research method of literature published by scientific journals in the period January 2010 to December 2021. The data used comes from published journals related to the topics studied and from various electronic media. The results of the study can find out strategies in the learning process in the implementation of society 5.0 in policies in the field of education as an effort to deal with the impact of the covid-19 pandemic.
\end{abstract}

Keywords: society 5.0, pandemi, covid-19

\section{PENDAHULUAN}

Pengaruh COVID-19 menyebabkan pada keberlanjutan pendidikan di Indonesia. Hal ini berkaitan dengan pilihan yang harus diambil melalui kebijakan Kementerian Pendidikan dan Kebidayaan Republik Indonesia (Kemdikbud RI) yang mewajibkan kegiatan pembelajaran di sekolah dan perguruan tinggi dilaksanakan di rumah masing-masing dengan menggunakan berbagai pilihan strategi pembelajaran. Pilihan ini dilakukan sebagai alternatif jalan keluar untuk memutus mata rantai penularan COVID-19. Jalan keluar dari permasalahan ini tentu melalui kegiatan pembelajaran yang dilakukan secara daring pada semua jenjang pendidikan untuk menyesuaikan Kebijakan Mendikbud melalui Surat Edaran Nomor 3 Tahun 2020 Tentang Pencegahan Corona Virus Disease (COVID-19) pada Satuan Pendidikan yang 
menyatakan untuk kegiatan pembelajaran tidak dilakukan di sekolah maupun perguruan tinggi (Kemdikbud RI, 2020).

Berdasarkan data UNESCO yang menggambarkan secara global, sebanyak 112 negara telah menerapkan kebijakan belajar dari rumah, antara lain Afrika Selatan, Austria, Jerman, Malaysia, Meksiko, Thailand, Yaman, dan Zambia. Dari 112 negara, sejumlah 101 negara mengimplementasikan kebijakan belajar dari rumah dalam skala nasional. Sementara 11 negara lainnya, menerapkan belajar di rumah di wilayah tertentu termasuk Indonesia (Mas'udi, 2020).

Dampak dari pandemi secara tidak langsung memaksa dunia pendidikan di Indonesia mempercepat era revolusi industri 4.0 dengan mengimplementasikan konsep society 5.0 yang ditandai dengan meningkatnya konektivitas, interaksi, perkembangan sistem digital, kecerdasan artifisial, dan virtual. Oleh karena itu, semakin memusatnya aktivitas antara manusia, mesin dan berbagai sumber daya, teknologi informasi dan komunikasi berdampak pada berbagai aktivitas dan kebiasaan manusia.

Era yang terus mengalami perubahan dan tidak ada siapapun yang sanggup menghindarinya. Sehingga hal ini membutuhkan sumber daya manusia (SDM) yang siap dalam menyesuaikan diri dan bersaing dalam perkembangan skala global. Salah satu meningkatkan kualitas SDM melalui bidang pendidikan adalah kunci menjamin dalam mengambil bagian perkembangan Revolusi Industri 4.0. Keberhasilan mengimbangi revolusi industri 4.0 di suatu negara, merupakan hasil dari peningkatan kapasitas kualitas pendidik seperti guru. Di era ini, pendidik dituntut menguasai berbagai keahlian menggunakan teknologi baru. Situasi ini seperti memaksa lembaga pendidikan mempersiapkan oritentasi dan literasi baru dalam perjalanan pendidikan di negara kita. Literasi lama yang mengandalkan baca, tulis dan berhitung harus diperkuat dengan literasi baru yaitu literasi data, teknologi dan sumber daya manusia. Literasi data adalah kemampuan beraktivitas membaca, menganalisa dan memanfaatkan informasi dari data yang didapatkan. Sedangkan literasi teknologi adalah kemampuan untuk memahami sistem mekanika dan teknologi dalam dunia kerja. Sedangkan literasi sumber daya manusia yakni kemampuan berinteraksi dengan baik, tidak kaku, dan berkarakter.

Berdasarkan laporan Pusat Inovasi dan Kajian Akademik (2020) Indonesia sedang melakukan perjalanan menuju ke arah Masyarakat 5.0 dan telah melalui beberapa tahap kehidupan bermasyarakat. Memasuki Masyarakat 5.0 keterjangkauan informasi menjadi lebih terbuka dan mudah diakses sesuai dengan keinginan pengguna, sehingga tahap kehidupan bermasyarakat akan mudah beradaptasi pada otomatisasi dan kecerdasan dari teknologi untuk mengatasi permasalahan kehidupan manusia. Integrasi teknologi ini sejalan dengan tujuan global pada Sustainable Development Goals (SDGs) sehingga ke depannya, Masyarakat 5.0 dapat mewujudkan kehidupan yang berkelanjutan.

Artikel ini dihasilkan dari penarasian ide-ide yang ada sebelumnya, baik dari hasil kajian riset, pendadaran ide tentang society 5.0 pada keadaan pandemi saat ini. Artikel ini diuraikan dengan tujuan untuk memberikan gambaran kesiapan Indonesia dan implementasi society 5.0 pada bidang pendidikan dalam kajian dimensi riset.

\section{METODE PENELITIAN}

Penelitian ini merupakan studi kepustakaan yaitu dengan menghimpun informasi yang relevan dengan implementasi kebijakan dan strategi society 5.0 dalam menghadapi pandemi. Penelitian ini menggunakan metode penelitian tinjauan sistematis terhadap literatur yang diterbitkan oleh jurnal ilmiah pada periode Januari tahun 2010 hingga Desember 2021. Sumber yang digunakan berasal dari jurnal-jurnal yang sudah dipublikasikan terkait dengan topik yang dikaji dan berbagai media elektronik.

Teknik pengumpulan data melalui proses studi penelaahan terhadap litertur-literatur, buku-buku, laporan-laporan, dan catatan-catatan yang memikili hubungan dengan konteks masalah yang dipecahkan, yaitu untuk mengetahui kebijakan dan strategi society 5.0 dalam proses pembelajaran sebagai upaya penanganan dampak pandemi. Upaya mengumpulkan informasi dimaksud dapat diperoleh dari buku-buku ilmiah, laporan penelitian, karangan- 
karangan ilmiah, tesis dan disertasi, peraturan-peraturan, ketetapan-ketetapan, buku tahunan, ensiklopedia dan sumber-sumber tertulis baik tercetak maupun elektronik lain.

Teknik analisis data menggunakan metode content analysis, yaitu dalam mendapatkan karakteristik yang jelas dari wacana berupa teori dan konsep yang dikaji, penulis menggunakan teknik analisis tersebut untuk inferensi yang dapat direplikasi (ditiru) dan kebenaran data untuk memerhatikan konteks permasalahan.

\section{HASIL PENELITIAN DAN PEMBAHASAN}

\section{Covid-19}

COVID-19 telah membuahkan krisis diberbagai aktivitas manusia, sehingga memaksa secara cepat untuk membuat pengelolaan dan kebijakan penanganan pandemi di berbagai negara. Hampir seluruh negara yang tanpa melihat status kemajuan ekonomi dan teknologi, serta kesiapan sektor pelayanan kesehatan, dipaksa menghadapi ketidakpastian dan ketidakyakinan di dalam belenggu COVID-19. Estándar sistem manajemen krisis yang ada saat ini, seolah kehilangan relevansi dan menekan pemerintah di berbagai negara untuk mengambil kebijakan yanke arah yang bersifat trial and error. COVID-19 menciptakan tantangan terhadap pengelolaan krisis pandemi yang bersifat unprecedented dalam konteks global (Mas'udi, 2020). Menurut Yuliana (2020) karakteristik pada Covid-19 ini adalah sebagai berikut:

- Tingkat penyebaran tinggi: Dalam waktu tiga bulan virus telah menyebar secara global dan dianggap sebagai pandemi global. Tingkat penyebarannya tinggi, yang terjadi karena mobilitas orang yang lebih tinggi dalam dunia yang saling terhubung dunia. Dapat dikatakan bahwa tingkat transmisi orang ke orang sangat tinggi.

- Orang tua dan kekebalan tubuh rendah lebih rentan: Data menunjukkan bahwa populasi berusia dan orang dengan kekebalan rendah (dengan diabetes atau penyakit kronis lainnya) lebih rentan terhadap virus ini.

- Tingkat pemulihan diferensial: Sementara rata-rata global tingkat pemulihan adalah relatif rendah (seperti 28 hingga 30\%), berbagai negara memiliki pemulihan diferensial menilai. Sementara China, Korea, Jepang memiliki pemulihan yang relatif tinggi tingkat, Eropa, Iran, AS menunjukkan tingkat pemulihan yang relatif lebih rendah. Dari Tentu saja, ini terus berubah, dan mudah-mudahan menjadi lebih baik segera.

\section{Dampak Pandemi Covid-19 Pada Pendidikan}

Tujuan pendidikan adalah proses perkembangan aspek kognitif, afektif, dan psikomotor seseorang atau kelompok, serta upaya mendewasakan manusia melalui kegiatan pembelajaran dan pendidikan. Pendidikan terjadi karena adanya interaksi saling memberi antara dua orang atau lebih, guru dan siswa, yang mengarah pada perubahan sikap dan perilaku menjadi lebih baik. Penutupan sekolah merupakan respons terhadap pandemi COVID-19 yang berdampak pada akses pendidikan. Ratusan ribu anak-anak dan remaja tidak bersekolah akibat penutupan sementara sebagai upaya memutus mata rantai penularan virus COVID-19. Dampak loss learning akan menjadi sesuatu hal yang ditakuti jika keadaan pandemi tidak segera ditemukan jalan keluarnya.

Pandemi COVID-19 telah mempercepat proses transformasi digital pengelolaan perguruan tinggi dan praktik pembelajarannya, yang selama ini diwacanakan secara tunggal sebagai akibat tuntutan kemajuan teknologi informasi digital. Sebaliknya, kemajuan teknologi informasi digital telah menjadi "dewa penolong" bagi pendidikan tinggi, yang secara memaksa penerapan secara konvensional dipaksa berhenti akibat gelombang pandemi. Jadi, disrupsi akibat pandemi tidak dapat dibaca di luar konteks Revolusi Industri 4.0. Di sisi lain, pemahaman tentang Revolusi Industri 4.0 tidak dapat dibatasi hanya pada proses disrupsi teknologi. Ada aspek nonteknologi dalam hal ini pandemi COVID-19 yang juga berperan menentukan dalam proses transformasi revolusioner pendidikan tinggi. Perubahan paradigma perguruan tinggi pada saat ini merupakan interface antara dorongan Revolusi Industri 4.0 dan dampak langsung pandemi COVID-19 (Mas'udi, 2020). 


\section{Society 5.0}

Era society 5.0. atau era masyarakat 5.0, adalah sebuah era, dimana masyarakatnya hidup di era industri 4.0. Era industri 4.0 adalah sebuah era yang aktifitas masyarakatnya saling terhubung dengan jaringan internet atau satelit, sehingga muncul paradigma, sebuah era hidup manusia yang sangat canggih. Era society 5.0 merupakan sebuah periode yang berpusat pada manusia (human centered) dan berlandaskan pada teknologi (technology based). Oleh karena itu, kecerdasan buatan (artificial intelligence) akan sepenuhnya didedikasikan untuk meningkatkan kemampuan manusia dalam menemukan dan membuka berbagai peluang yang dimiliki oleh manusia.

Menurut Cahyadiana (2019) era ini membutuhkan sumber daya manusia yang dibutuhkan di era society 5.0, antara lain: 1) leadership, 2) language, 3) IT Literacy, dan 4) writing skill. Jadi, era society 5.0 memaksa sumber daya manusia yang mumpuni, artinya, memiliki kapasitas dibidang keilmuannya dan mengaplikasikan dalam kehidupan tanpa menghilangkan nilai-nilai luhur sesuai keyakinannya.

Menurut Pusat Inovasi dan Kajian Akademik UGM (2020), masyarakat 5.0 (Society 5.0) adalah sebuah konstelasi kehidupan masyarakat yang berpusat pada penyelarasan kebutuhan manusia secara efektif dan efisien, yang dapat mengimbangi kemajuan teknologi dan ekonomi melalui pemecahan berbagai permasalahan sosial, dengan memanfaatkan sistem yang menghubungkan ruang siber (cyber space) dan ruang fisik (physical space) secara terpadu. Konsep ini bertujuan menciptakan masyarakat yang dapat bertahan oleh berbagai permasalahan dan tantangan sosial yang dihadapi dengan memanfaatkan inovasi dari revolusi industri. Inovasi ini termasuk teknologi:

- Big Data,

- Artificial Intelligence

- Internet of Things (IoT)

\section{Big Data}

Istilah "big data" menggambarkan kumpulan data yang sangat besar dan kompleks sehingga aplikasi konvensional tidak dapat memprosesnya secara memadai. Istilah ini juga mengacu pada alat dan teknologi yang digunakan untuk menangani big data. Contoh implementasi big data adalah jumlah data yang disajikan setiap hari melalui Internet seperti, Google maps, video YouTube, Twitter feeds, data graphic position system dan sebagainya (Agustini, 2017).

Perkembangan jenis dan jumlah data yang semakin meningkat berkali-kali lipat di dunia maya merupakan fakta yang tidak bisa dipungkiri. Era teknologi informasi dan komunikasi semakin berkembang sesuai dengan kemajuan teknologi saat ini. Menurut Gartner dalam Santos (2015), big data terdiri dari tiga atribut yaitu volume, variety, dan velocity. Berdasarkan studi yang dilakukan oleh IBM, ketiga komponen big data tersebut dilengkapi dengan komponen Veracity dan Value.

Menurut Gartner dalam Santos (2015), big data terdiri dari tiga atribut, yaitu volume, variety, dan velocity. Sedangkan, berdasarkan riset yang dilakukan oleh IBM, ketiga komponen big data tersebut di atas ditambah dengan komponen veracity dan value.

Menurut Sin dan Muthu (2015), teknik pemanfaatan big data dapat dimanfaatkan dalam berbagai kegiatan menganalisis pembelajaran, seperti;

a. Performance Prediction: memprediksi perkembangan peserta didik melalui analisis interaksi antar siswa dan interaksi siswa dengan guru di setiap pembelajaran.

b. Attrition Risk Detection: menganalisis perilaku siswa yang memiliki risiko drop out dalam pembelajaran. Dapat di deteksi dan diukur di awal pembelajaran sehingga dapat meminimalkan risiko DO.

c. Data Visualization: Laporan data pendidikan yang divisualisasikan dalam beberapa desain untuk memudahkan mengidentifikasi tren dan hubungan antar data. 
d. Intelligent Feedback: sistem pembelajaran yang menyediakan intelligent feedback dengan merespon input siswa untuk segera meningkatkan capaian hasil belajar.

e. Course Recommendation: sebuah alternatif peningkatan kapasitas baru peserta didik yang dapat direkomendasikan berdasarkan ketertarikan siswa, yang teridentifikasi melalui aktivitas mereka. Hal ini untuk menjamin agar siswa tidak akan salah dalam memilih bidang ilmu yang sesuai bakat dan minatnya.

f. Student Skill estimation: mengestimasi ketercapaian kemampuan siswa

g. Behavior Detection: menganalisis perilaku siswa berbasis pada aktivitas dan games model yang membantu mengembangkan diri terhadap bakat dan minatnya.

h. Constructing courseware, Developing concept maps, Grouping \& collaboration of Student, Social Network Analysis, dan Planning and scheduling.

\section{Artificial Intelligence}

Artificial Intelligence (AI) adalah sebuah kecerdasan buatan yang merupakan bagian dari sistem pembelajaran komputer pada suatu rangkaian sistem komputer yang dapat menunjukkan karakteristik perilaku manusia, seperti mengerti suatu bahasa, mempelajari, mempertimbangkan dan memecahkan suatu masalah (Fitrajaya, 2010)

AI sebagai bagian dari teknologi yang berkembang terus dieksplorasi karena membutuhkan mesin yang sangat bagus dan mahal tetapi dapat berdampak positif pada pembelajaran sekarang dan di masa depan. Seiring hal tersebut, biaya pendidikan akan semakin mahal menuntut adaptasi perubahan adanya kebijakan.

AI yang menjadi dasar pengembangan mesin dapat membantu manusia dalam memecahkan berbagai masalah dengan mengeksplorasi sisi kognitif manusia, sistem memori dan karakter dalam menemukan jalan keluar permasalahan tersebut, sehingga melahirkan suatu penemuan yang berdampak pada proses pendidikan. AI berdasarkan program pengajaran yang dikenal sebagai intelligent tutor atau intelligent coaches, berkembang pada bagian-bagian kurikulum sekolah.

Dunia pendidikan setelah melalui seperempat abad lebih melakukan penelitian dan pengembangan, kuantitas beberapa aplikasi AI masih terhitung sangat sedikit yang dihasilkan dan dikembangkan lebih lanjut. Namun keadaan ini ternyata menjadi pemicu perkembangan baru setelah beberapa poin penting akhirnya diketahui, yaitu hubungan antara desain dan sistem pakar, representasi kemampuan manusia dalam menggunakan program komputer dan persepsi manusia itu sendiri. Hingga lahirnya intelligent computer-aided teaching (ICAI), kemajuan signifikan telah dicapai dalam pengembangannya.

Implementasi AI saat ini mampu menyelesaikan berbagai tugas seperti aotumatic programming, problem-solving, control of robots, perception and pattern recognation,natural language processing, game playing, information storage and retrieval, dan computational logic. Sistem ICAI dapat mengatasi area ini. Dengan ICAI berbasis tutorial, ada beberapa langkah yang terlibat dalam menjelaskan dan memecahkan masalah, menyimpan dan memproses data, bermain game, mendiagnosis kesalahan konseptual siswa, dan memberikan natural language dialogue dengan siswa.

\section{Internet of Things}

Internet of Things (IoT) adalah suatu kegiatan interaksi antara subjek dan objek dengan memanfaatkan internet. Pemanfaatan IoT terdapat dalam berbagai aktivitas, misalnya: banyaknya transportasi online, e-commerce, pemesanan tiket online, live streaming, e-learning dan lain-lain bahkan hingga alat bantu untuk bidang tertentu seperti sensor suhu jarak jauh, GPS tracking, dan sebagainya yang menggunakan internet atau jaringan sebagai media untuk melakukannya. Dalam bidang pendidikan, IoT mampu melakukan segala aktivitas dengan menggunakan sistem yang terorganisir dan tertata, serta memiliki sistema dokumentasi yang tepat (Meutia, 2015). 
Pada bidang pendidikan, IoT sangat diperlukan untuk proses pembelajaran dengan segala aktivitasnya yang menggunakan sistem terkontrol, sehingga menghasilkan keluaran dokumen untuk tata kelola yang tertata dengan baik. Masalah yang rumit dan membutuhkan waktu yang lama akan dapat diselesaikan dengan baik menggunakan komputer dan internet. Permasalahan pendidikan yang telah diambil jalan keluarnya antara lain sistem KRS secara online, pembelajaran jarak jauh, semakin mudahnya interaksi antara sekolah atau universitas lain dalam menyelenggarakan kerjasama pendidikan. Untuk mendukung segala aktivitas di dunia pendidikan dapat dilengkapi dengan hal ini, sehingga perkembangan kemampuan yang dimiliki semakin handal dan terintegrasi melalui cloud computing. Hal penting ini akan membentuk manusia yang memiliki karakter terdidik sehingga diperlukan cara yang tepat, cerdas dan efisien.

Pendidikan di era saat ini membutuhkan teknologi internet dalam pembelajaran dari segi operasional atau pada prosesnya. Implementasi smart school dengan teknologi Internet of Things dapat memecahkan masalah dalam proses pembelajaran dan memiliki keandalan yang tinggi karena terintegrasi dengan cloud computing (Cordiaz, 2018)

\section{Permasalahan Pendidikan Indonesia}

Sebelum adanya pandemi Covid-19, sistem pendidikan Indonesia telah memiliki dua persoalan besar yang harus dihadapi. Pertama, bangsa Indonesia secara internal masih menghadapi krisis multidimensi, persatuan nasional yang longgar, demokratisasi di segala bidang kehidupan, desentralisasi pemerintahan, dan kualitas pendidikan belum yang tidak menunjukkan daya saing. Kedua, masyarakat Indonesia menghadapi tantangan eksternal di pasar dunia, kemajuan teknologi yang menuntut pendidikan secara kompetitif, inovatif dan modal jejaring tanpa batas.

Krisis multidimensi yang melanda Indonesia pada tahun 1997 berdampak besar terhadap kualitas sumber daya manusia (SDM) Indonesia dan juga bagi kualitas pendidikan di Indonesia. Hal ini terlihat pada indikator makro yaitu pencapaian Indeks Pembangunan Manusia (IPM) dan indikator mikro seperti kemampuan literasi.

Implementasi society 5.0 dalam keadaan pandemi saat ini merupakan strategi yang tepat dalam keberlanjutan pendidikan di Indonesia. Hal ini dikarenakan agar pendidikan kita mengalami keberlanjutan. Mengingat bahwa kualitas pendidikan di indonesia cenderung menurun ketika menghadapi sebuah krisis. Melihat situasi negara yang dilanda krisis demi krisis, memiliki makna bahwa pihak yang berkiprah dalam dunia pendidikan ikut merasa prihatin terhadap apa yang akan terjadi dengan generasi penerus bangsa di masa depan.

Abad ke-21 sebagai abad keterbukaan atau globalisasi. Seiring hal tersebut, Griffin, Patrick, Barry McGraw, Esther Care (2012) menegaskan bahwa, muatan pembelajaran diharapkan mampu memenuhi century skills, yakni 1) inovasi pada pembelajaran dan keterampilan meliputi penguasaan aspek pengetahuan dan keterampilan yang kompleks, inovasi kegiatan belajar, berpikir kritis dalam menyelesaikan masalah, komunikasi dalam menciptakan kolaborasi, dan kreativitas, 2) keterampilan literasi digital yang terdiri dari literasi media, literasi informasi, dan literasi ICT, 3) kecakapan hidup dalam berkarir meliputi fleksibilitas, adaptabilitas, inisiatif, interaksi sosial dan budaya, produktivitas dan akuntabilitas, dan kepemimpinan yang bertanggung jawab.

Generasi Z merupakan orang-orang yang lahir pada kurun waktu sejak tahun 1995 sampai dengan tahun 2010. Generasi ini memiliki intensitas yang tinggi dalam memanfaatkan teknologi informasi dan komunikasi. Mereka perlu dibekali dengan ketrampilan berpikir kritis, berpikir inovatif, pemecahan masalah dan interaksi sosial.

Saat ini, individu yang berusia 18 dan 23 tahun tersebut hidup pada kemajuan teknologi. Generasi ini memiliki kecenderungan belajar yang sepenuhnya terlibat dalam proses pembelajaran. Mereka akan selalu mencoba interaktif karena memiliki tantangan dan menikmati diskusi kelompok dan selalu diberikan kepercayaan mencari sumber seluas-luasnya. Bagi mereka belajar adalah kegiatan tanpa batas, mereka dapat belajar di mana saja dan kapan 
saja dan memiliki akses tidak terbatas ke informasi baru. Mereka memberi perhatian pada pembelajaran yang melibatkan kolaborasi aktif dengan anggota tim dan belajar di tempat lain selain kelas. Selain itu, penggunaan alat digital dan forum online menjadi lebih disukai, mereka lebih suka terintegrasi dalam proses pembelajaran mereka. Karena siswa Gen Z sangat menyukai alat digital, mereka berharap alat tersebut tersedia kapan pun mereka membutuhkannya dengan hambatan akses yang rendah. Siswa Gen $\mathrm{Z}$ ini perlu mempersiapkan diri berkembang dalam Revolusi Industri 4.0.

Kebijakan mengenai belajar dari rumah juga merupakan langkah yang tepat untuk mengurangi risiko penularan wabah ini dengan baik. Pengendalian masa diperlukan karena keadaan kesehatan masyarakat menjadi perhatian utama dalam masa seperti ini. Penggunaan teknologi dengan tepat menjadi strategi utama yang dapat diimplementasikan menjadi sebuah jalan keluar masalah pembelajaran.

\section{Kebijakan dan Strategi}

Pada perkembangannya hampir tidak ada satu negara pun yang benar-benar kebal dari COVID-19, termasuk Indonesia. Pemerintah melalui Kementerian Pendidikan dan Kebudayaan (Kemendikbud) melakukan berbagai adaptasi dan berorientasi pada pembelajaran yang tidak membebani guru maupun siswa, namun penuh makna dan nilai-nilai penguatan karakter seiring perkembangan status darurat Covid-19.

Penyesuaian ini tertuang dalam Surat Edaran Nomor 2 Tahun 2020 tentang Pencegahan dan Penanganan Covid-19 di Lingkungan Kementerian Pendidikan dan Kebudayaan serta Surat Edaran Nomor 3 Tahun 2020 tentang Pencegahan Covid-19 di Satuan Pendidikan. Serangkaian kebijakan dikeluarkan dalam menanggapi perkembangan penyebaran Covid-19 dengan pendekatan keseriusan menerapkan protokol kesehatan, seperti pelaksanaan pembelajaran jarak jauh, penyesuaian ujian sekolah, pembatalan ujian nasional (UN), dan pendaftaran siswa secara online sesuai Surat Edaran Nomor 4 Tahun 2020 tentang Pelaksanaan Kebijakan Pendidikan di Masa Darurat. Penyebaran Penyakit Virus Corona (Covid-19). Selain itu, ada kebijakan penyesuaian penggunaan Bantuan Operasional Sekolah (BOS) fleksibel untuk memenuhi kebutuhan sekolah di masa pandemi.

Pada gambar 1. menunjukkan skema implementasi society 5.0 dalam pendidikan selama pandemi. Prinsip dasar dari kebijakan ini adalah mengenai kesehatan dan keselamatan masyarakat selama pandemi dengan melakukan aktivitas pendidikan yang dilakukan dari rumah dengan memanfaatkan sarana digital. Hal ini dilakukan agar pendidikan berjalan secara berkelanjutan.

Implementasi society 5.0 tentu membutuhkan beberapa aspek yang mendukung agar berjalan dengan baik. Aspek-aspek tersebut membantu meningkatkan kualitas dari sebuah sistem agar efektif dan efisien. Aspek pertama, yaitu finance. Aspek ini memberikan pengaruh agar program-program sesuai dengan anggaran dana yang tersedia dengan pengeluaran yang operasional pada sistem yang berjalan. 


\section{Society 5.0 dalam Pendidikan selama Pandemi}

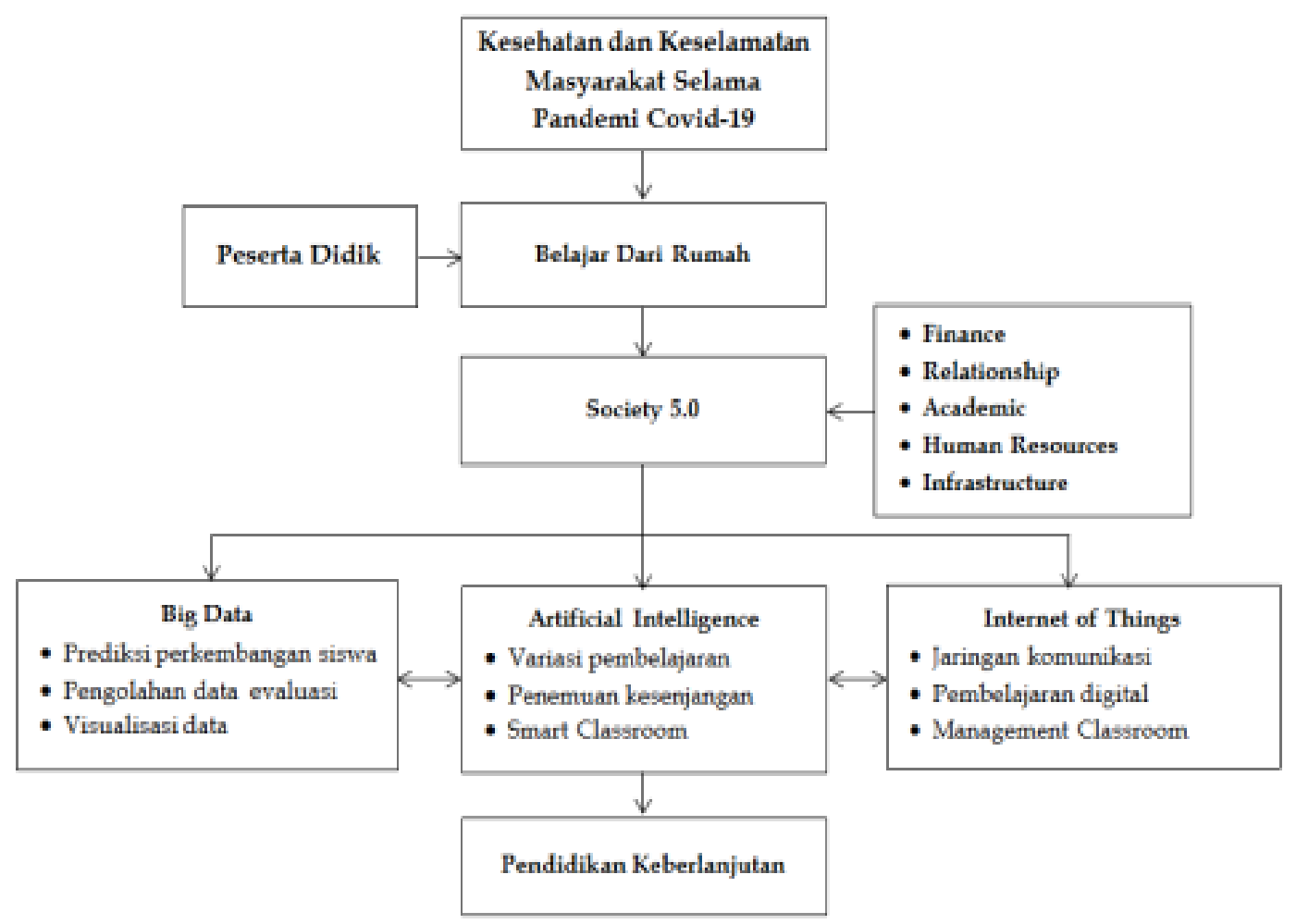

Gambar 1. Skema Society 5.0 dalam pendidikan selama pandemi

Kedua yaitu academic. Proses pembelajaran yang baik terjadi karena adanya pendidik dan peserta didik yang aktif dalam kegiatan belajar mengajar untuk untuk mencapai tujuan pendidikan yang maksimal. Ketiga, yaitu relationship. Aspek ini menghubungkan semua stakeholder dalam pendidikan untuk saling berkoorinasi dalam dinamika pembelajaran yang terjadi selama pandemi.

Keempat, yaitu human resources. Kualitas sumber daya manusia dalam implementasi society 5.0 menjadi kunci pelaksanaan kegiatan belajar mengajar. Hal ini memiliki keterkaitan dengan prinsip human centered yang berada pada sistem ini. Kelima, yaitu infrastructure. Pada aspek ini manajemen ketersedian sarana dan prasarana yang mampu memudahkan kegiatan dari program-program yang akan dijalankan.

Tabel 1. Peluang dan Tantangan Society 5.0 dalam Pendidikan

\begin{tabular}{|c|c|}
\hline Peluang & Tantangan \\
\hline $\begin{array}{l}\text { - } \text { Berkembangnya kelas sosial menengah } \\
\text { - } \text { Generasi alpha yang akrab teknologi digital } \\
\text { - } \text { Terapan pada berkembangnya teknologi } \\
\text { - } \text { Meningkatnya volume data } \\
\text { - } \text { Investasi bidang teknologi } \\
\text { - } \text { Berkembangnya perusahaan rintisan } \\
\text { - } \quad \text { Meningkatnya penetrasi internet } \\
\text { - } \quad \text { Meningkatnya pengguna telepon pintar }\end{array}$ & $\begin{array}{ll}\text { - } & \text { Kemampuan sumber daya manusia } \\
\text { - } & \text { Kemampuan literasi digital } \\
\text { - } & \text { Pemahaman konsep di masyarakat } \\
\text { - } & \text { Kolaborasi antar sektor } \\
\text { - } & \text { Risiko teknologi: privasi dan keamanan data } \\
\text { - } & \text { Kebijakan dalam teknologi digital } \\
\text { - } & \text { Keselarasan dan sinergitas pemerintah } \\
\text { - } & \text { Pemerataan infrastruktur digital } \\
\text { - } & \text { Penyediaan pedoman dan mekanisme } \\
\text { - } & \text { Integrasi kurikulum dengan dunia digital }\end{array}$ \\
\hline
\end{tabular}


Pada tabel 1. dapat diketahui peluang dan tantangan yang dihadapi dalam society 5.0 pada masa pandemi sehingga dapat diketahui beberapa alternatif dalam strategi dalam perkembangan pendidikan di era pandemi ini yang berkaitan dengan society 5.0, yaitu sebagai berikut:

1. Meningkatkan kemampuan sumber daya manusia dalam hal ini pendidik dengan memanfaatkan perkembangan teknologi dengan modal dinamika arus informasi dan komunikasi.

2. Melakukan kolaborasi antar sektor antara pemerintah dan lembaga-lembaga yang terkait dalam hal kesamaan visi di bidang pendidikan untuk meningkatkan kepercayaan masyarakat dalam menghadapi perubahan.

3. Memperluas investasi untuk menentukan anggaran yang dijalankan yang sesuai dengan program-program dalam jangka pendek sampai jangka panjang.

4. Pemerataan infrastruktur digital untuk meningkatkan pemanfaatan teknologi dalam menjangkau seluruh wilayah dan berbagai sektor.

5. Menyusun regulasi yang tidak menghambat perkembangan industri digital yang berkaitan dengan investasi, penyedia jasa dan penggunanya.

6. Mengembangkan kurikulum yang mengintegrasikan pembelajaran dengan pemanfaatan teknologi digital.

\section{KESIMPULAN}

Sistem pendidikan di Indonesia termasuk memiliki perkembangan secara dinamis mengikuti perubahan zaman. Pendidikan menjadi aspek yang mendesak dalam kejadian krisis. Krisis dalam pandemi Covid-19 memberikan pembelajaran, dengan menambah deretan alasan penting bahwa teknologi saat ini menjadi sebuah jalan keluar permasalahan sebuah keterbatasan ruang dan waktu.

Pola Integrasi pendidikan dan teknologi saat ini telah berkembang menjadi konsep Society 5.0 yang mampu menjawab tantangan keberlanjutan. Dimana pada era ini telah berubah untuk merespon Revolusi Industri 4.0 yang bertujuan meningkatkan kualitas lulusan dari segi soft skill, kompetensi teknologi digital dan pemanfaatannya. Implementasi artificial intelligence, big data, dan internet of things pada setiap ruang lingkup tata kelola pendidikan dalam skala besar maupun pembelajaran pada skala kecil. Hal tersebut terjadi pada setiap proses pembelajaran di semua jenjang pendidikan dan manusia sebagai subjek menjadi pembelajar sepanjang hayat.

Melalui Pendidikan 4.0, peserta didik diharapkan memiliki sikap, pengetahuan, dan keterampilan yang dibutuhkan selama hidupnya, terutama untuk mengantisipasi perubahan, menghayati dan bermanfaat bagi masyarakat, serta memanfaatkan inovasi-inovasi dari revolusi industri. Pencapaian kompetensi yang tepat akan mampu menjawab peluang dan tantangan zaman. Satu hal yang menjadi inisiatif penting agar segera diwujudkan adalah penyelenggaraan pendidikan terpadu dengan sintesis pemikiran penelitian dan pengabdian kepada masyarakat. Hal ini untuk menciptakan lulusan yang mampu beradaptasi di lingkungan pekerjaan berbasis IT dan mengelola gelombang revolusi industri menuju cita-cita dan harmonisasi kehidupan.

\section{DAFTAR PUSTAKA}

Agustini, Ketut. (2017). Inovasi Teknologi dalam Pendidikan melalui Big Data Analytic dan Personalized Learning. Prosiding Seminar Nasional Pendidikan Teknik Informatika (SENAPATI) Ke-8. Bali, 9 September 2017.

Arjunaita, A., (2020). Pendidikan di Era Revfolusi Industri 5.0. In Prosiding Seminar Nasional Program Pascasarjana Universitas PGRI Palembang.

Cahyadiana, Windarini. (2020). Sumber Daya Manusia Unggul Menyongsong Era Society 5.0. Pendidikan, Bisnis, dan Manajemen Menyongsong Era Society 5.0. Malang, Penerbit Baskara Media. 
Cordiaz, Muhammad. (2018). Penerapan Smart Campus sebagai Pendukung Kegiatan Pendidikan dalam Tri Dharma Perguruan Tinggi. Jurnal Informatika Universitas Pamulang. Vo. 2, No. 2, Juni 2018.

Fitrajaya, Eka., dkk. (2010). Pengembangan Modul Pembelajaran Berbasis Kecerdasan Buatan Guna Deteksi Kesalahan Siswa.

Griffin, Patrick, Barry McGraw, Esther Care (ed). (2012). Assessment and Teaching of 21 St Century Skills. Esther Care Melbourne.

Jee, Youngmaee. (2020). WHO International Health Regulations Emergency Commite for the Covid-19 Outbreak. epiH Epidemiology and Health. Volume 42, e2020013.

Kemdikbud RI. (2020). Edaran Tentang Pencegahan Wabah COVID-19 di Lingkungan Satuan Pendidikan Seluruh Indonesia.

Mas'udi, Wawan., Poppy Winanti. (2020). Tata Kelola Penanganan Covid-19 Di Indonesia: Kajian Awal. Yogyakarta: Gadjah Mada University Press.

Meutia, E. D. (2015). Internet of Things - Keamanan dan Privasi. Seminar Nasional dan Expo Teknik Elektro, pp. 85-89, 2015.

Muhyiddin. (2020). Covid-19. Covid 19, New Normal dan Perencanaan Pembangunan di Indonesia. The Journal of Develompent Planning. Volume IV No. 2 No. 2020.

Pusat Inovasi dan Kajian Akademik. (2019). Ekosistem Pendidikan untuk Masyarakat 5.0. Newsletter Pusat Inovasi dan Kajian Akademik (PIKA). Edisi Mei 2019.

Santos, Renato P D. (2015). Big Data: Philosophy, Emergence, Crowdledge, and Science Education. Themes In Science and Technology Education. Vol. 8, No. 2, pp. 115-127, 2015.

Shibata, M., Ohtsuka, Y., Okamoto, K. and Takahashi, M., (2017). Toward an Efficient Search Method to Capture the Future MOT Curriculum Based on the Society 5.0. In 2017 Portland International Conference on Management of Engineering and Technology (PICMET) (pp. 1-7). IEEE.

Sin, Katrina dan Loganahan Muthu. (2015). Application of Big Data in Education Data Mining and Learning Analytics - A Literature Review. ICTACT Journal on Soft Computing. Special Issue on Spot Computing Models for Big Data. July 2015, Volume 05 Issue 04.

Yuliana. 2020. Coronavirus Diseases (Covid-19); Sebuah Tinjauan Literatur. Wellness and Healthy Magazine. Volume 2, Nomor 1, February 2020, p. 187 -192. 